\title{
Effects of soya milk and Bifidobacterium-fermented soya milk on plasma and liver lipids, and faecal steroids in hamsters fed on a cholesterol-free or cholesterol-enriched diet
}

\author{
H. Kikuchi-Hayakawa*, N. Onodera, S. Matsubara, E. Yasuda, \\ Y. Shimakawa and F. Ishikawa \\ Yakult Central Institute for Microbiological Research, Kunitachi, Tokyo, Japan
}

(Received 25 February 1997-Revised 2 June 1997-Accepted 24 June 1997)

\begin{abstract}
The effects of freeze-dried soya milk (SM) and Bifidobacterium-fermented soya milk (FSM) on plasma and liver lipids, and faecal steroid excretion were estimated in hamsters fed on a cholesterol-free or cholesterol-enriched diet. Hamsters fed on the cholesterol-free diet containing $300 \mathrm{~g}$ FSM $/ \mathrm{kg}$ had lower levels of plasma VLDL + LDL cholesterol than the animals fed on the control diet. SM in the diet produced a similar pattern without significant differences. In the cholesterol-enriched diet group, SM and FSM decreased the levels of plasma total cholesterol and VLDL + LDL-cholesterol. SM and FSM decreased the plasma triacylglycerol level in both the cholesterol-free and -enriched diet groups. The liver total cholesterol contents in the SM and FSM groups were lower than that in the control group, for hamsters fed on the cholesterol-free diet. The liver triacylglycerol content was not modified by SM or FSM in hamsters fed on either the cholesterol-free or -enriched diet. SM and FSM increased the total bile acid excretion and the proportion of cholesterol entering the cholic acid biosynthesis pathway in both the cholesterol-free and -enriched diet groups. SM and FSM did not affect neutral steroid excretion in the cholesterol-free or -enriched diet group. There was an inverse relationship between VLDL + LDL-cholesterol and faecal bile acid excretion in hamsters fed on the cholesterol-free $(r-0.670, P<0.01)$ and cholesterol-enriched $(r-0.761$, $P<0.001$ ) diets respectively. These results indicated that SM had an anti-atherogenic effect, and that this effect was not diminished by prior fermentation.
\end{abstract}

Soya milk: Bifidobacterium: Cholesterol: Bile acids

The potential role of dietary soya in the prevention and treatment of chronic diseases, in particular, heart disease and cancer, has been recognized for a long time. Soyabean protein (Sugano \& Koba, 1993), isoflavonoids (Sharma, 1978), phospholipids (Knuiman et al. 1989), saponins (Potter et al. 1993), and phytate (Jariwalla et al. 1990) have been investigated in a search for the active component responsible for the anti-atherogenic effect of soya. Some experiments suggested that the amino acid profile of proteins and other non-protein components present in soya may be partially responsible for the hypocholesterolaemic effect (Huff et al. 1977; Nagata et al. 1982; Anthony et al. 1996; Balmir et al. 1996; Potter et al. 1996). However, the mechanism and component responsible for the effect remain unclear.
Many types of soya food are consumed throughout the world. A new class of soya food is being developed to reduce soya's bean-like flavour, for incorporation into human foods. Soya milk is an aqueous extract of whole soyabeans. However many people find the taste of soya milk undesirable. Soya milk contains soyabean protein and isoflavones, which are thought to have an anti-atherogenic effect. The combination of soyabean protein and minor components may be important (Anthony et al. 1996). The fermentation of soya results in compositional changes in isoflavones, phytate and saponins (Anderson \& Wolf, 1995). Bifidobacterium breve YIT 4065, which is used as a commercial fermented milk starter in Japan, is suitable for the fermentation of soya milk. Bifidobacterium breve YIT 4065 produces lactate and acetate, which could change the 
physicochemical character of soyabean protein, and cause the release of aglycones from isoflavone glucosides by $\beta$ glucosidase (EC 3.2.1.21) (Ishikawa et al. 1997).

Terpstra et al. (1991) showed that the hamster is a useful animal model for studying the effects of dietary proteins on lipid metabolism in the presence and absence of dietary cholesterol. Hamsters are known to have similar responses to human subjects with respect to dietary influences on blood lipids. An ethanol extract of isolated soyabean protein, which contains isoflavones, caused a more sensitive response to blood lipids in hamsters than in rats (Balmir et al. 1996).

To determine the effect of the fermentation of soya milk on lipid metabolism, we investigated the levels of cholesterol and triacylglycerol in plasma and liver, and faecal steroids in hamsters fed on a cholesterol-free or cholesterol-enriched diet with soya milk fermented with Bifidobacterium breve YIT 4065.

\section{Materials and methods}

\section{Preparation of soya milk and fermented soya milk}

Crude soya milk from Shikokukakouki Co. Ltd (Tokushima, Japan) was used as the starting material for fermented soya milk. Bifidobacterium breve YIT 4065 was obtained from the collection of the Culture Collection Research Laboratory of Yakult Central Institute for Microbiological Research (Tokyo, Japan). A seed culture prepared anaerobically in the soya milk was freshly added to the soya milk at $10 \mathrm{ml} / 1$ and fermented statically at $37^{\circ}$ for $30 \mathrm{~h}$. The titratable acidity, $\mathrm{pH}$ and viable cell counts of the fermented soya milk were $0.825 \%$, 4.84 and $4.04 \times 10^{9}$ colony forming units $/ \mathrm{ml}$ respectively. The original unfermented soya milk and the fermented soya milk were freeze-dried and milled until the products passed through a $0.84 \mathrm{~mm}$ sieve $(20 \mathrm{mesh})$. The crude protein, crude fat and ash content levels in the freeze-dried soya milk (SM) were 431,227 and $55 \mathrm{~g} / \mathrm{kg}$ respectively. The crude protein, crude fat and ash content levels in the freezedried fermented soya milk (FSM) were 429, 233 and $57 \mathrm{~g} / \mathrm{kg}$ respectively.

\section{Animals and diets}

Thirty-six male Golden Syrian hamsters (Japan S.L.C. Co., Shizuoka, Japan) were obtained at the age of 5 weeks. The animals were fed on a commercial non-purified solid diet (MF; Oriental Yeast, Tokyo, Japan) for $2 \mathrm{~d}$ and the powdered MF diet for $5 \mathrm{~d}$. After this $7 \mathrm{~d}$ adaptation period, the hamsters were randomly divided into six groups of six each of similar mean body weights. The composition of the cholesterol-free basal diet was $(\mathrm{g} / \mathrm{kg})$ : casein 200 , maize oil 10 , lard 90 , cellulose 50 , vitamin mixture 20 , mineral mixture 40 , choline bitartrate 2 , and $\alpha$-maize starch 588 . The composition of the cholesterol-enriched basal diet was $(\mathrm{g} / \mathrm{kg})$ : casein 200 , maize oil 10 , lard 90 , cellulose 50 , vitamin mixture 20 , mineral mixture 40 , choline bitartrate 2 , cholesterol 5, and $\alpha$-maize starch 583. The vitamin and mineral mixtures were those of AIN-76 (American Institute of Nutrition, 1977). The control mixture contained $431 \mathrm{~g}$ casein and $227 \mathrm{~g}$ maize oil $/ \mathrm{kg}$ instead of the protein and oil in soya milk, and $342 \mathrm{~g}$ sucrose $/ \mathrm{kg}$. Hamsters were fed on one of the following six diets for $7 \mathrm{~d}$ : (1) a cholesterol-free basal diet that contained $300 \mathrm{~g}$ control mixture $/ \mathrm{kg}$, (2) a cholesterol-free basal diet that contained $300 \mathrm{~g} \mathrm{SM} / \mathrm{kg}$, (3) a cholesterol-free basal diet that contained $300 \mathrm{~g} \mathrm{FSM} / \mathrm{kg}$, (4) a cholesterol-enriched basal diet that contained $300 \mathrm{~g}$ control mixture $/ \mathrm{kg}$, (5) a cholesterol-enriched basal diet that contained $300 \mathrm{~g} \mathrm{SM} / \mathrm{kg}$ or, (6) a cholesterol-enriched basal diet that contained $300 \mathrm{~g} \mathrm{FSM} / \mathrm{kg}$. The final compositions of the diets are shown in Table 1. The animals were allowed free access to food and water. Food consumption was recorded every 2 or $3 \mathrm{~d}$. The hamsters were housed individually in stainless-steel wire-bottomed cages in a room with controlled lighting (lights on 08.30 20.30 hours), temperature $\left(24 \pm 2^{\circ}\right)$, and humidity $(60 \pm 5 \%)$. The animals were maintained in accordance with the guidelines of the Ethical Committee for Animal Experiments of Yakult Central Institute. After $5 d$ adaptation to the experimental diet, food intake and body weight were recorded, and faeces were collected for $2 \mathrm{~d}$. The faeces were lyophilized and then stored at $-20^{\circ}$ until analysis of neutral steroids and bile acids. On the seventh day of the experimental diet period, the hamsters were anaesthetized with an intraperitoneal injection of pentobarbital sodium (Nembutal ${ }^{\circledR}$, Abbott Laboratories,

Table 1. Compositions of the experimental diets

\begin{tabular}{|c|c|c|c|c|c|c|}
\hline & \multicolumn{3}{|c|}{ Cholesterol-free diet } & \multicolumn{3}{|c|}{ Cholesterol-enriched diet } \\
\hline & Control & Soya milk & $\begin{array}{l}\text { Fermented } \\
\text { soya milk }\end{array}$ & Control & Soya milk & $\begin{array}{l}\text { Fermented } \\
\text { soya milk }\end{array}$ \\
\hline Soya milk & - & 30 & - & - & 30 & - \\
\hline Fermented soya milk & - & - & 30 & - & - & 30 \\
\hline Casein & 26.94 & 14 & 14 & 26.94 & 14 & 14 \\
\hline Maize oil & 7.51 & 0.7 & 0.7 & 7.51 & 0.7 & 0.7 \\
\hline Lard & $6 \cdot 3$ & 6.3 & $6 \cdot 3$ & $6 \cdot 3$ & $6 \cdot 3$ & $6 \cdot 3$ \\
\hline Cellulose & 3.5 & 3.5 & 3.5 & 3.5 & 3.5 & 3.5 \\
\hline Vitamin mixture $^{\star}$ & 1.4 & $\uparrow .4$ & 1.4 & 1.4 & 1.4 & 1.4 \\
\hline Mineral mixture & 2.8 & 2.8 & 2.8 & 2.8 & 2.8 & 2.8 \\
\hline Choline bitartrate & 0.14 & 0.14 & 0.14 & 0.14 & 0.14 & 0.14 \\
\hline Cholesterol & - & - & - & 0.35 & 0.35 & 0.35 \\
\hline Sucrose & 10.25 & - & - & 10.25 & - & - \\
\hline$\alpha$-Maize starch & 41.16 & $41 \cdot 16$ & $41 \cdot 16$ & 40.81 & 40.81 & 40.81 \\
\hline
\end{tabular}

"The vitamin and mineral mixtures were those of AIN-76 (American Institute of Nutrition, 1977). 
Chicago, IL, USA), $25 \mathrm{mg} / \mathrm{kg}$ body weight. Food was withheld for $4 \mathrm{~h}$ before death. Blood was collected from the aorta ventralis into tubes containing EDTA and then separated by centrifugation at $2000 \mathrm{~g}$ for $15 \mathrm{~min}$ at $4^{\circ}$. The livers were perfused in situ with saline $(9 \mathrm{~g} \mathrm{NaCl} / \mathrm{l})$, removed, weighed, and then kept in plastic bags at $-20^{\circ}$ until analysis of liver lipids.

\section{Analytical methods}

Diet. Crude protein, diethyl ether extract (crude lipid), and crude ash analyses of SM and FSM were carried out by the method of the Association of Official Analytical Chemists (1990). Isoflavones in the SM and FSM diets were analysed by HPLC as follows. For the measurement of free isoflavones, $0.1 \mathrm{~g}$ sample was extracted with $4 \mathrm{ml}$ methanol $(80 \mathrm{ml} / \mathrm{l})$. $\mathrm{HCl}(4 \mathrm{M}, 2 \mathrm{ml})$ and $1 \mathrm{ml}$ flavone (4 $\mu \mathrm{g} / \mathrm{ml}$; Tokyo Kasei Co., Tokyo, Japan) as an internal standard were added to $2 \mathrm{ml}$ of the extract. For measurement of total isoflavones, $0.1 \mathrm{~g}$ sample was extracted with $4 \mathrm{ml}$ methanol $(80 \mathrm{ml} / 1)$. The extract $(2 \mathrm{ml})$ was hydrolysed with $2 \mathrm{ml} 4 \mathrm{M}-\mathrm{HCl}$ at $100^{\circ}$ for $30 \mathrm{~min}$. The mixture was cooled to room temperature and then $1 \mathrm{ml}$ flavone $(4 \mu \mathrm{g} / \mathrm{ml})$ was added as an internal standard. Free and total isoflavone were analysed by HPLC (LC Module I; Waters, Millipore Japan, Tokyo, Japan) equipped with a YMC-Pack C4 column (YMC Co., Kyoto, Japan) and a u.v. detector $(260 \mathrm{~nm})$. The flow rate of the mobile phase (acetate (100 ml/1)-methanol, $73: 27 \mathrm{v} / \mathrm{v})$ was maintained at $2.0 \mathrm{ml} / \mathrm{min}$. The column temperature was $50^{\circ}$. Daidzein (Sigma Chemical Co., St Louis, MO, USA) and genistein (Seikagaku Corporation Co., Tokyo, Japan) were used as standard substances. Daidzin and genistin were estimated as total and free isoflavones.

Plasma lipids. Plasma total cholesterol and triacylglycerol concentrations were measured enzymically with commercial kits (Determiner TC555; Kyowa Medics, Tokyo, Japan and Triglyceride G Test Wako; Wako Junyaku, Osaka, Japan respectively). Plasma HDL-cholesterol was measured after precipitation with heparin-Mn reagent and the supernatant fraction was assayed for cholesterol with a commercial kit (HDL Cholesterol Test Wako, Wako Junyaku). VLDL-cholesterol plus LDLcholesterol was calculated as the difference between total cholesterol and HDL-cholesterol. The atherogenic index (AI) was calculated as the VLDL + LDL-cholesterol : HDL cholesterol ratio.

Liver lipids. Liver lipids were extracted by the method of Folch et al. (1957). The liver total cholesterol and triacylglycerol concentrations were measured as described earlier.

Faecal neutral steroid excretion. Faeces were lyophilized and any hair and food attached to the faeces was removed. Homogenized faecal matter $(30-70 \mathrm{mg})$, with 5 $x$-cholestane as an internal standard, was saponified and extracted according to the method of Grundy et al. (1965). The solvent was evaporated under $\mathrm{N}_{2}$ gas and the residue was dissolved in $500 \mu \mathrm{l}$ chloroform. N, O-bis(trimethylsilyl)trifluoroacetamide $(250 \mu \mathrm{l}$, BSTFA; Pierce Chemical Co., Rockford, IL, USA) and $5 \mu$ l trimethylchlorosilane
(Pierce Chemical Co.) were added for silylation at $80^{\circ}$ for 2 h. A GC system (model 5890; Yokogawa-HewlettPackard, Tokyo, Japan) equipped with a $30 \mathrm{~m} \times 0.32 \mathrm{~mm}$ i.d. capillary glass column coated with SPB-1 FS (Supelco, Belfonte, PA, USA) was used for the analysis. The initial conditions were as follows: oven, $220^{\circ}$; injector, $220^{\circ}$; flame ionization detector (FID), $280^{\circ}$; and carrier gas flow rate, $0.8 \mathrm{ml} / \mathrm{min}$. Cholesterol, cholestanol, coprostanol, epicoprostanol, cholestanone and coprostanone, obtained from GL Science Inc. (Tokyo, Japan), and $\beta$-sitosterol, stigmasterol and campesterol, obtained from Tama Biochemical Co. (Tokyo, Japan), were used as standard substances.

Faecal bile acid excretion. Lyophilized faeces (40$60 \mathrm{mg}$ ) with $200 \mu 11 \mathrm{mM}-5 \beta$-pregnan- $3 \alpha, 17 \alpha, 20 \alpha$-triol were extracted with $5 \mathrm{ml}$ ethanol at $80^{\circ}$. The ethanol was removed under $\mathrm{N}_{2}$ gas, and then the residue was dissolved in methanol and passed through a $0.45 \mu \mathrm{m}$ filter (C3 LH; Millipore Japan, Tokyo, Japan). The bile acids were analysed by HPLC by the method of Ishimoto (1986). The standard substances used were cholic acid, glycocholic acid, taurocholic acid, chenodeoxycholic acid, glycochenodeoxycholic acid, taurochenodeoxycholic acid, deoxycholic acid, glycodeoxycholic acid, taurodeoxycholic acid, lithocholic acid, glycolithocholic acid, taurolithocholic acid, ursodeoxycholic acid, glycoursodeoxycholic acid and tauroursodeoxycholic acid from JASCO (Tokyo, Japan).

Organic acids. The organic acid contents of the SM and FSM were determined by the method of Kikuchi \& Yajima (1992).

\section{Statistical analysis}

The results are expressed as means and pooled SD. The means were compared using STATISTICA software (StatSoft, Inc., OK, USA), by ANOVA and subsequent Tukey's HSD comparisons after logarithmic transformation to stabilize the variance, if the variance was significant (Bartlett test) (Zar, 1984). The difference was considered to be statistically significant when $P$ was less than $0 \cdot 05$.

\section{Results \\ Chemical compositions of soya milk and fermented soya milk}

The lactic, acetic and formic acid contents of the SM were $0.2,12.1$ and $0.4 \mu \mathrm{mol} / \mathrm{g}$ respectively; and those of the FSM were $225.7,187.1$ and $20.7 \mu \mathrm{mol} / \mathrm{g}$ respectively. The isoflavone composition of each diet is shown in Table 2. The SM and FSM diets contained the same amount of total isoflavone. The FSM diet contained five and sixty times higher quantities of daidzein and genistein than the SM diet respectively.

\section{Growth and digestibility}

In the hamsters that were fed on the cholesterol-free diet, no significant differences in the final body weight, body-weight 
Table 2. Isoflavone concentrations in the hamster diets $(\mu \mathrm{g} / \mathrm{g}$ diet)

\begin{tabular}{lccccc}
\hline Diet & Daidzein & Genistein & Daidzin* & Genistin* & Total \\
\hline Cholesterol-free diet & & & & & \\
$\quad$ Soya milk & 13.2 & 3.2 & 214.0 & 324.8 & 555.2 \\
$\quad$ Fermented soya milk & 64.0 & 213.7 & 161.6 & 111.6 & 550.9 \\
Cholesterol-enriched diet & & & & & \\
$\quad$ Soya milk & 12.1 & 3.3 & 207.1 & 310.6 & 533.1 \\
$\quad$ Fermented soya milk & 63.9 & 213.5 & 159.1 & 106.0 & 542.4 \\
\hline
\end{tabular}

"Values are presented as the amounts of aglycones.

gain or food efficiency ratio were detected (Table 3). The food intake was greater in the hamsters fed on SM or FSM than in the control diet group. The apparent digestibility of DM was lower in the SM and FSM groups than in the control group.

In the animals that received the cholesterol-enriched diet, no significant differences in the final body weight were observed (Table 3). The body-weight gain, food intake and food efficiency ratio were greater in the hamsters fed on SM or FSM than in the control group. However, the apparent digestibility of DM was lower in the SM and FSM groups than in the control group.

\section{Plasma lipid concentrations}

Among hamsters fed on the cholesterol-free diet, the plasma total cholesterol level was not affected by the diet (Table 4). The plasma triacylglycerol level was approximately $50 \%$ lower than the control level in the hamsters fed on SM or FSM. The FSM diet increased the HDLcholesterol level and decreased the VLDL + LDL-cholesterol level by $25 \%$, and consequently decreased the $\mathrm{AI}$ value. The HDL-cholesterol level in the SM group was not significantly different from that in the controls. The
VLDL + LDL-cholesterol level in the SM group was lower than that in the controls, but not significantly. The control group had the highest AI value and the FSM group the lowest value; the level in the SM group was intermediate but was not significantly different from the control and FSM groups.

Among hamsters fed on the cholesterol-enriched diet (Table 4), the plasma total cholesterol level was about $15 \%$ lower in both the SM and FSM groups than in the control group. The plasma triacylglycerol level was about $75 \%$ lower than that of the controls in hamsters fed on SM or FSM. Both SM and FSM increased the HDL-cholesterol level and decreased the VLDL + LDL-cholesterol level, and consequently decreased the $\mathrm{AI}$ value.

\section{Liver lipid contents}

Among hamsters fed on the cholesterol-free diet, the wet and dry liver weights were not different in the three groups (control, SM and FSM) (Table 5). The liver total cholesterol contents in the SM and FSM groups were lower than that in the control group. The liver triacylglycerol content was not affected by SM or FSM.

Table 3. Body weights, food intake, and apparent digestibility of DM in hamsters fed on cholesterol-free or cholesterol-enriched diets containing soya milk or fermented soya milk*

(Mean values for six hamsters and pooled standard deviation)

\begin{tabular}{|c|c|c|c|c|c|}
\hline & Control & $\begin{array}{l}\text { Soya } \\
\text { milk }\end{array}$ & $\begin{array}{l}\text { Fermented } \\
\text { soya milk }\end{array}$ & Pooled SD & ANOVA $(P<)$ \\
\hline $\begin{array}{l}\text { Cholesterol-free diet } \\
\text { Initial body wt }(\mathrm{g}) \\
\text { Final body wt }(\mathrm{g}) \\
\text { Body wt gain }(\mathrm{g} / \mathrm{d}) \\
\text { Food intake }(\mathrm{g} / \mathrm{d}) \\
\text { Food efficiency } \dagger \\
\text { DM digestibility }(\%)\end{array}$ & $\begin{array}{c}95 \cdot 6^{\mathrm{a}} \\
107 \cdot 1^{\mathrm{a}} \\
1.6^{\mathrm{a}} \\
7.2^{\mathrm{a}} \\
0.23^{\mathrm{a}} \\
94.9^{\mathrm{a}}\end{array}$ & $\begin{array}{c}95 \cdot 3^{\mathrm{a}} \\
110 \cdot 9^{\mathrm{a}} \\
2 \cdot 2^{\mathrm{a}} \\
8 \cdot 0^{\mathrm{a}} \\
0.28^{\mathrm{a}} \\
92 \cdot 7^{\mathrm{b}}\end{array}$ & $\begin{array}{c}94 \cdot 9^{\mathrm{a}} \\
107 \cdot 9^{\mathrm{a}} \\
1.9^{\mathrm{a}} \\
7 \cdot 9^{\mathrm{a}} \\
0 \cdot 23^{\mathrm{a}} \\
92 \cdot 4^{\mathrm{b}}\end{array}$ & $\begin{array}{l}6.1 \\
6.6 \\
0.5 \\
0.7 \\
0.05 \\
1.3\end{array}$ & $\begin{array}{r}\text { NS } \\
\text { NS } \\
\text { NS } \\
0.05 \\
\text { NS } \\
0.01\end{array}$ \\
\hline $\begin{array}{l}\text { Cholesterol-enriched die } \\
\text { Initial body wt }(\mathrm{g}) \\
\text { Final body wt }(\mathrm{g}) \\
\text { Body wt gain }(\mathrm{g} / \mathrm{d}) \\
\text { Food intake }(\mathrm{g} / \mathrm{d}) \\
\text { Food efficiency } \dagger \\
\text { DM digestibility }(\%)\end{array}$ & $\begin{array}{c}95 \cdot 4^{\mathrm{a}} \\
103 \cdot 3^{\mathrm{a}} \\
1 \cdot 1^{\mathrm{b}} \\
6.5^{\mathrm{b}} \\
0.17^{\mathrm{b}} \\
95.1^{\mathrm{a}}\end{array}$ & $\begin{array}{c}95 \cdot 2^{\mathrm{a}} \\
110 \cdot 0^{\mathrm{a}} \\
2 \cdot 1^{\mathrm{a}} \\
7.7^{\mathrm{a}} \\
0.27^{\mathrm{a}} \\
92.9^{\mathrm{b}}\end{array}$ & $\begin{array}{c}95 \cdot 3^{\mathrm{a}} \\
110 \cdot 3^{\mathrm{a}} \\
2 \cdot 1^{\mathrm{a}} \\
8 \cdot 1^{\mathrm{a}} \\
0 \cdot 27^{\mathrm{a}} \\
93 \cdot 3^{\mathrm{b}}\end{array}$ & $\begin{array}{l}6.2 \\
7.3 \\
0.6 \\
0.8 \\
0.07 \\
1.3\end{array}$ & $\begin{array}{l}\text { NS } \\
\text { NS } \\
0.001 \\
0.001 \\
0.01 \\
0.01\end{array}$ \\
\hline
\end{tabular}

a,b Mean values within a row with unlike superscript letters were significantly different, $P<0.05$ (Tukey's test).

* For details of diets, see Table 1.

† Food efficiency = body-weight gain/food intake . 
Table 4. Plasma lipid concentrations in hamsters fed on cholesterol-free or cholesterolenriched diets containing soya milk or fermented soya milkł (Mean values for six hamsters and pooled standard deviation)

\begin{tabular}{|c|c|c|c|c|c|}
\hline & Control & Soya milk & $\begin{array}{l}\text { Fermented } \\
\text { soya milk }\end{array}$ & Pooled SD & $\begin{array}{c}\text { ANOVA } \\
(P<)\end{array}$ \\
\hline $\begin{array}{l}\text { Cholesterol-free diet } \\
\text { Total cholesterol (mmol/l) } \\
\text { Triacylglycerol }(\mathrm{mmol} / \mathrm{l}) \\
\text { HDL-cholesterol (mmol/l) } \\
\text { VLDL + LDL-cholesterol (mmol/l) } \\
\text { Atherogenic index* } \dagger\end{array}$ & $\begin{array}{l}4 \cdot 2^{\mathrm{a}} \\
5 \cdot 5^{\mathrm{a}} \\
2 \cdot 1^{\mathrm{b}} \\
2 \cdot 1^{\mathrm{a}} \\
1 \cdot 05^{\mathrm{a}}\end{array}$ & $\begin{array}{l}3 \cdot 8^{\mathrm{a}} \\
2 \cdot 3^{\mathrm{b}} \\
2 \cdot 1^{\mathrm{ab}} \\
1.7^{\mathrm{ab}} \\
0.84^{\mathrm{ab}}\end{array}$ & $\begin{array}{l}4 \cdot 0^{\mathrm{a}} \\
2 \cdot 7^{\mathrm{b}} \\
2 \cdot 4^{\mathrm{a}} \\
1 \cdot 6^{\mathrm{b}} \\
0.66^{\mathrm{b}}\end{array}$ & $\begin{array}{l}0.32 \\
0.002 \\
0.26 \\
0.38 \\
0.12\end{array}$ & $\begin{array}{l}\text { NS } \\
0.0001 \\
0.05 \\
0.05 \\
0.05\end{array}$ \\
\hline $\begin{array}{l}\text { Cholesterol-enriched diet } \\
\text { Total cholesterol (mmol/l) } \\
\text { Triacylglycerol" (mmol/l) } \\
\text { HDL-cholesterol (mmol/l) } \\
\text { VLDL+LDL-cholesterol } \dagger(\mathrm{mmol} / \mathrm{l}) \\
\text { Atherogenic index } \dagger\end{array}$ & $\begin{array}{l}6 \cdot 4^{\mathrm{a}} \\
9 \cdot 2^{\mathrm{a}} \\
2 \cdot 1^{\mathrm{b}} \\
4 \cdot 3^{\mathrm{a}} \\
2 \cdot 07^{\mathrm{a}}\end{array}$ & $\begin{array}{l}5 \cdot 4^{\mathrm{b}} \\
2 \cdot 1^{\mathrm{b}} \\
2.7^{\mathrm{a}} \\
2.7^{\mathrm{b}} \\
1.03^{\mathrm{b}}\end{array}$ & $\begin{array}{l}5 \cdot 4^{\mathrm{b}} \\
2 \cdot 2^{\mathrm{b}} \\
2 \cdot 5^{\mathrm{a}} \\
2 \cdot 8^{\mathrm{b}} \\
1 \cdot 13^{\mathrm{b}}\end{array}$ & $\begin{array}{l}0.68 \\
0.004 \\
0.30 \\
0.003 \\
0.15\end{array}$ & $\begin{array}{l}0.01 \\
0.0001 \\
0.0001 \\
0.001 \\
0.0001\end{array}$ \\
\hline
\end{tabular}

Among hamsters fed on the cholesterol-enriched diet, the mean dry liver weight in the FSM group was $15 \%$ heavier than that in the controls. The liver cholesterol and triacylglycerol contents were not affected by diet (control, SM and FSM).

\section{Faecal steroid excretion}

The total neutral steroid excretion values were similar in the control, SM and FSM groups, in both the cholesterolfree diet and cholesterol-enriched diet hamsters (Table 6). In the animals that received the cholesterol-free diet, none of the neutral steroids was affected by the diets. Hamsters in the SM and FSM diet groups excreted more cholesterol and epicoprostanol than the controls. The hamsters fed with SM or FSM excreted less coprostanol than those on the control diets, but not significantly.
Among the animals that were fed on the cholesterol-free diet, the total bile acid excretion was four- and fivefold higher in the hamsters fed on SM and FSM diets respectively, than in those on the control diets (Table 7). The proportion of deoxycholic acid in the SM and FSM groups was twofold higher than the control group value, and that of lithocholic acid in the SM and FSM groups was $30 \%$ lower than that in the controls. Consequently, the proportion of bile acids originating from the cholic acid biosynthesis pathway in the SM and FSM groups was higher than that in the control group.

Total bile acid excretion was fivefold higher than the control group value in hamsters fed on the cholesterolenriched diet with SM or FSM (Table 8). The proportion of deoxycholic acid in the SM and FSM groups was twofold higher than that in the control group, and lithocholic acid in the SM and FSM hamsters was $20 \%$ lower than the control group level. Consequently, the proportion of bile acids

Table 5. Liver weights and liver lipid concentrations in hamsters fed on cholesterol-free or cholesterol-enriched diets containing soya milk or fermented soya milk*

(Mean values for six hamsters and pooled standard deviation)

\begin{tabular}{|c|c|c|c|c|c|}
\hline & Control & Soya milk & $\begin{array}{l}\text { Fermented } \\
\text { soya milk }\end{array}$ & Pooled SD & $\begin{array}{c}\text { ANOVA } \\
(P<)\end{array}$ \\
\hline $\begin{array}{l}\text { Cholesterol-free diet } \\
\text { Dry liver wt (g) } \\
\text { Total cholesterol (mg/liver) } \\
\text { Triacylglycerol (mg/liver) }\end{array}$ & $\begin{array}{l}1 \cdot 65^{\mathrm{a}} \\
33 \cdot 2^{\mathrm{a}} \\
56 \cdot 7^{\mathrm{a}}\end{array}$ & $\begin{array}{l}1 \cdot 69^{\mathrm{a}} \\
20 \cdot 4^{\mathrm{b}} \\
47 \cdot 9^{\mathrm{a}}\end{array}$ & $\begin{array}{l}1.69^{\mathrm{a}} \\
22 \cdot 3^{\mathrm{b}} \\
48 \cdot 9^{\mathrm{a}}\end{array}$ & $\begin{array}{l}0.13 \\
8.2 \\
7.5\end{array}$ & $\begin{array}{l}\text { NS } \\
0.01 \\
\text { NS }\end{array}$ \\
\hline $\begin{array}{l}\text { Cholesterol-enriched diet } \\
\text { Dry liver wt (g) } \\
\text { Total cholesterol (mg/liver) } \\
\text { Triacylglycerol (mg/liver) }\end{array}$ & $\begin{array}{c}1.76^{b} \\
120 \cdot 9^{a} \\
52 \cdot 8^{a}\end{array}$ & $\begin{array}{c}1.98^{\mathrm{ab}} \\
134.9^{\mathrm{a}} \\
52.8^{\mathrm{a}}\end{array}$ & $\begin{array}{c}2.02^{\mathrm{a}} \\
135.5^{\mathrm{a}} \\
51.3^{\mathrm{a}}\end{array}$ & $\begin{array}{r}0.2 \\
12.9 \\
8.9\end{array}$ & $\begin{array}{l}0.05 \\
\text { NS } \\
\text { NS }\end{array}$ \\
\hline
\end{tabular}

\footnotetext{
a,b Mean values within a row not sharing a common superscript letter were significantly different $P<0.05$ (Tukey's test).
}

* For details of diets, see Table 1. 
Table 6. Faecal neutral steroid excretion $(\mathrm{mg} / 2 \mathrm{~d})$ in hamsters fed on cholesterol-free or cholesterol-enriched diets containing soya milk or fermented soya milk ${ }^{\star}$

(Mean values for six hamsters and pooled standard deviation)

\begin{tabular}{|c|c|c|c|c|c|}
\hline & Control & Soya milk & $\begin{array}{l}\text { Fermented } \\
\text { soya milk }\end{array}$ & Pooled SD & $\begin{array}{c}\text { ANOVA } \\
(P<)\end{array}$ \\
\hline \multicolumn{6}{|c|}{ Cholesterol-free diet } \\
\hline Cholesterol & 0.28 & 0.21 & 0.31 & 0.10 & NS \\
\hline Cholestanol & 0.31 & 0.38 & 0.31 & 0.22 & NS \\
\hline Coprostanol & 2.61 & 2.37 & $2 \cdot 14$ & 0.81 & NS \\
\hline Epicoprostanol & 0.13 & 0.13 & 0.39 & 0.22 & NS \\
\hline Total & 3.33 & 3.09 & 3.18 & 0.86 & NS \\
\hline \multicolumn{6}{|c|}{ Cholesterol-enriched diet } \\
\hline Cholesterol & $0.60^{\mathrm{a}}$ & $1.24^{b}$ & $1 \cdot 13^{b}$ & 0.44 & 0.05 \\
\hline Cholestanol & $0.25^{\mathrm{a}}$ & $0.64^{\mathrm{b}}$ & $0.39^{a b}$ & 0.23 & 0.01 \\
\hline Coprostanol & 9.34 & 7.78 & 7.41 & 1.67 & NS \\
\hline Epicoprostanol & $0.00^{\mathrm{a}}$ & $1.38^{b}$ & $1 \cdot 15^{\mathrm{b}}$ & 0.90 & 0.01 \\
\hline Total & 10.19 & 11.03 & 10.09 & 1.54 & NS \\
\hline
\end{tabular}

originating from the cholic acid biosynthesis pathway in these SM and FSM groups was higher than that in the control group.

\section{Discussion}

The aim of the present study was to determine the effect of soya milk, unfermented or fermented with Bifidobacterium, on plasma and faecal steroid excretion. SM and FSM diets decreased plasma VLDL + LDL-cholesterol and triacylglycerol levels, and remarkably enhanced faecal bile acid excretion. There was an inverse relationship between faecal bile acid excretion and plasma VLDL + LDL-cholesterol in both the animals fed on the cholesterol-free diet $(r-0.670$, $P<0.01)$ and those fed on the cholesterol-enriched diet $(r-0.761, P<0.001)$. Studies on rats (Nagata et al. 1982) and rabbits (Huff \& Carroll, 1980) have also shown that soyabean protein increases faecal bile acid excretion. These findings, and the results of the present study, suggest that hepatic cholesterol metabolism could change in order to provide more cholesterol for bile acid synthesis.
The cholic: chenodeoxycholic acid ratio in the SM and FSM groups was greater than that in the controls. Two pathways of bile acid biosynthesis, cholesterol $7 \alpha$-hydroxylase and mitochondrial $27 \alpha$-hydroxylase, have been described for mammalian liver (Russell \& Setchell, 1992). Bile acid metabolism, especially the change in the cholic: chenodeoxycholic acid ratio in bile or faeces, has been associated with thyroid hormones (Jackson et al. 1993), diabetes (Uchida et al. 1985), oestrogen (Van Erpecum et al. 1991), cholesterol 7 $\alpha$-hydroxylase deficiency (Schwarz et al. 1996), and ageing (Uchida et al. 1978). Feeding soyabean protein alters hormone concentrations (Sanchez \& Hubbard, 1991; Forsythe, 1995) and these may change bile acid metabolism. In rats, cholesterol feeding led to an increase in the chenodeoxycholic : cholic acid ratio (Uchida, 1992). However, cholesterol feeding did not affect this ratio in the hamsters in the present study (Tables 7 and 8). This difference between rats and hamsters may be due to different regulation of hepatic $7 \alpha$ hydroxylase (Horton et al. 1995; Pandak et al. 1995) to dietary cholesterol. Cholic acid, but not chenodeoxycholic

Table 7. Faecal bile acid excretion in hamsters fed on cholesterol-free diets containing soya milk or fermented soya milk* (Mean values for six hamsters and pooled standard deviation)

\begin{tabular}{lccccc}
\hline & Control & Soya milk & Fermented soya milk & Pooled SD & ANOVA $(P<)$ \\
\hline Total bile acid excretion (mmol/2 d) & $1.68^{\mathrm{b}}$ & $6.69^{\mathrm{a}}$ & $8.06^{\mathrm{a}}$ & 3.28 & 0.0001 \\
Bile acid composition (\%) & & & & \\
Ursodeoxycholic acid & $8.15^{\mathrm{a}}$ & $1.68^{\mathrm{b}}$ & $3.48^{\mathrm{b}}$ & 3.96 & 0.01 \\
Cholic acid & $0.11^{\mathrm{b}}$ & $3.88^{\mathrm{a}}$ & $4.07^{\mathrm{a}}$ & 1.94 & 0.0001 \\
Glycochenodeoxycholic acid & 0 & 0.08 & 0 & 0.12 & $\mathrm{NS}$ \\
Glycodeoxycholic acid & $0^{\mathrm{b}}$ & $0.68^{\mathrm{a}}$ & $0.91^{\mathrm{a}}$ & 0.51 & 0.001 \\
Taurodeoxycholic acid & $4.75^{\mathrm{a}}$ & $3.37^{\mathrm{b}}$ & $6.11^{\mathrm{a}}$ & 1.9 & 0.05 \\
Deoxycholic acid & $19.11^{\mathrm{b}}$ & $43.85^{\mathrm{a}}$ & $43.99^{\mathrm{a}}$ & 12.81 & 0.0001 \\
Lithocholic acid & $67.88^{\mathrm{a}}$ & $46.45^{\mathrm{b}}$ & $41.44^{\mathrm{c}}$ & 12.14 & 0.0001 \\
Cholic acid pathway bile acids $\dagger$ & $23.96^{\mathrm{b}}$ & $51.80^{\mathrm{a}}$ & $55.08^{\mathrm{a}}$ & 14.51 & 0.0001 \\
Chenodeoxycholic acid pathway bile acids $\ddagger$ & $76.04^{\mathrm{a}}$ & $48.20^{\mathrm{b}}$ & $44.92^{\mathrm{b}}$ & 14.86 & 0.0001 \\
\hline
\end{tabular}

a.b.c Mean values within a row not sharing a common superscript letter were significantly different, $P<0.05$ (Tukey's test).

* For details of diets, see Table 1.

† Cholic acid, glycodeoxycholic acid, taurodeoxycholic acid and deoxycholic acid.

‡ Ursodeoxycholic acid, glycochenodeoxycholic acid and lithocholic acid. 
Effects of soya milk and fermented soya milk

Table 8. Faecal bile acid excretion in hamsters fed on cholesterol-enriched diets containing soya milk or fermented soya milk* (Mean values for six hamsters and pooled standard deviation)

\begin{tabular}{lccccc}
\hline & Control & Soya milk & Fermented soya milk & Pooled SD & ANOVA $(P<)$ \\
\hline Total bile acid excretion (mmol/2 d) & $1.73^{\mathrm{b}}$ & $7.73^{\mathrm{a}}$ & $8.95^{\mathrm{a}}$ & 3.5 & 0.0001 \\
Bile acid composition (\%) & & & & & \\
Ursodeoxycholic acid & $6.14^{\mathrm{a}}$ & $1.38^{\mathrm{b}}$ & $1.34^{\mathrm{b}}$ & 2.43 & 0.0001 \\
Cholic acid & $0.73^{\mathrm{b}}$ & $3.77^{\mathrm{a}}$ & $4.38^{\mathrm{a}}$ & 0.10 & 0.0001 \\
Glycochenodeoxycholic acid & 0 & 0.18 & 0.04 & 0.15 & $\mathrm{NS}$ \\
Glycodeoxycholic acid & $0.46^{\mathrm{b}}$ & $1.27^{\mathrm{a}}$ & $0.97^{\mathrm{ab}}$ & 0.54 & 0.05 \\
Taurodeoxycholic acid & 4.49 & 3.62 & 4.39 & 1.71 & $\mathrm{NS}$ \\
Deoxycholic acid & $19.74^{\mathrm{c}}$ & $37.43^{\mathrm{b}}$ & $41.99^{\mathrm{a}}$ & 10.25 & 0.0001 \\
Lithocholic acid & $68.44^{\mathrm{a}}$ & $52.27^{\mathrm{b}}$ & $46.9^{\mathrm{c}}$ & 9.83 & 0.0001 \\
Cholic acid pathway bile acids $\dagger$ & $25.42^{\mathrm{b}}$ & $46.09^{\mathrm{a}}$ & $51.73^{\mathrm{a}}$ & 11.67 & 0.0001 \\
Chenodeoxycholic acid pathway bile acids & $74.58^{\mathrm{a}}$ & $53.83^{\mathrm{b}}$ & $48.28^{\mathrm{b}}$ & 12.01 & 0.0001 \\
\hline
\end{tabular}

a,b,c Mean values within a row not sharing a common superscript letter were significantly different, $P<0.05$ (Tukey's test).

* For details of diets, see Table 1.

$\uparrow$ Cholic acid, glycodeoxycholic acid, taurodeoxycholic acid and deoxycholic acid.

¥ Ursodeoxycholic acid, glycochenodeoxycholic acid and lithocholic acid.

acid promotes cholesterol absorption (Uchida et al. 1980). Therefore, an increase in the cholic acid pathway: chenodeoxycholic acid pathway ratio may promote cholesterol absorption. However, faecal cholesterol excretion was not affected in this study.

On the other hand, a cholesterol-lowering effect of soyabean protein without enhancement of bile acid excretion has been observed in monkeys (Jaskiewicz et al. 1987) and human subjects (Fumagalli et al. 1982). Soyabean protein and other non-protein components present in soyabeans may be partially responsible for the hypocholesterolaemic effect observed in some experiments (Huff et al. 1977; Nagata et al. 1982; Anthony et al. 1996; Balmir et al. 1996; Potter et al. 1996).

Soyabean protein containing isoflavones was reported to have favourable effects on plasma lipid and lipoprotein concentrations compared with alcohol-extracted soyabean protein (Anthony et al. 1996). Compositional changes in isoflavones, phytic acid, saponins and trypsin inhibitor occur during processing of soyabeans, and these components vary not only in quantity but also in availability (Anderson \& Wolf, 1995). Bifidobacterium breve YIT 4065 has $\beta$-glucosidase activity and is therefore able to release aglycones from isoflavonoid glucosides (Ishikawa et al. 1997). In this study, $25 \%$ of daidzin and $65 \%$ of genistin released their aglycones on fermentation. The plasma genistein concentration at $2 \mathrm{~h}$ after dosing in genisteintreated rats was higher than that in soya extract-treated rats, although there were no significant differences at $8 \mathrm{~h}$ or later (King et al. 1996). Isoflavones have weak oestrogenic effects and their functioning as both oestrogen agonists and antagonists in vitro has been reported (Martin et al. 1978; Mathieson \& Kitts, 1980). Oestrogen, when taken orally, increases the level of HDL (Schaefer et al. 1983; Applebaum-Bowden et al. 1989; Sacks \& Walsh, 1990), and lowers that of LDL (Schaefer et al. 1983; Sacks \& Walsh, 1990). It has been reported that post-menopausal women who take oestrogen generally have lower rates of cardiovascular disease than women of similar age who do not take it (Stampfer et al. 1991). Some reports suggest that isoflavones may be influential in the cholesterol-lowering effect of soya due to their oestrogen-like action (Potter, 1995; Anthony et al. 1996).

We found that fermented soya milk affected the plasma lipoprotein composition in animals fed on both cholesterolenriched and cholesterol-free diets. Soya milk had a similar effect, but this was not significant in hamsters fed on the cholesterol-free diet. Most clinical trials have revealed a decrease in the serum or plasma cholesterol concentration when animal protein in the diet is replaced by soyabean protein, and the decrease is generally greater in hypercholesterolaemic than in normocholesterolaemic subjects (Carroll, 1991). The FSM diet also had a tendency to produce greater faecal bile acid excretion than the SM diet, but this was not significant.

Bifidobacterium breve YIT 4065 produces lactate and acetate, which can modify the physicochemical properties of soyabean protein. The viscosity of the fermented soya milk was very high (1573 $\mathrm{mPa}$ s), whereas that of the soya milk was $13.4 \mathrm{mPa}$ s. The viscosity of a meal can regulate its physiological effect, such as the gastric emptying rate in man (Meyer et al. 1986). Carr et al. (1996) showed that both $e x$ vivo viscosity and cholesterol absorption were significantly correlated with the plasma cholesterol concentration, emphasizing the importance of the small intestine in mediation of cholesterol metabolism. In the present study, ex vivo viscosity was not estimated. The DM digestibility of soya milk and fermented soya milk was lower (Table 3) and the undigested fraction of soyabean protein decreased the serum cholesterol level more than the original soyabeans, with faecal bile acid excretion (Sugano et al. 1990), suggesting that the undigested fraction may have had a physiological effect in the small intestine of the hamsters in this study.

Plant sterols can affect cholesterol absorption (Vahouny et al. 1983). In the present study, the total contents of plant sterols ( $\beta$-sitosterol, stigmasterol and campesterol) in the SM, FSM and control diets were $0.5,0.4$ and $0.4 \mathrm{mg} / \mathrm{g}$ cholesterol-free diet respectively, and $0.4,0.6$ and $0.4 \mathrm{mg} / \mathrm{g}$ cholesterol-enriched diet. This difference might not have contributed to the plasma lipid findings. Phospholipids (Knuiman et al. 1989) and phytic acid (Jariwalla et al. 
1990) can reduce the plasma cholesterol level, but large amounts of phospholipids and phytic acid are required for the cholesterol-lowering effect.

In conclusion, soya milk had an anti-atherogenic effect, and this effect was not diminished by prior fermentation.

\section{Acknowledgements}

We wish to thank the staff of our laboratory animal facility for the careful maintenance of the hamsters. We are also grateful to Dr Aiyama and Mr Harada for the helpful advice regarding the analysis of isoflavones and neutral sterols.

\section{References}

American Institute of Nutrition (1977) Report of the American Institute of Nutrition ad hoc committee on standards for nutritional studies. Journal of Nutrition 107, 1340-1348.

Anderson RL \& Wolf WJ (1995) Compositional changes in trypsin inhibitors, phytic acid, saponins and isoflavones related to soyabean processing. Journal of Nutrition 125, 581S-588S.

Anthony MS, Clarkson TB, Hughes JRCL, Morgan TM \& Burke GL (1996) Soybean isoflavones improve cardiovascular risk factors without affecting the reproductive system of peripubertal Rhesus monkeys. Journal of Nutrition 126, 43-50.

Applebaum-Bowden D, Mclean P, Steinmettz A, Fontana D, Matthys C, Warnick GR, Cheung M, Albers JJ \& Hazzard WR (1989) Lipoprotein, apoprotein, and lipolytic enzyme changes following estrogen administration in postmenopausal women. Journal of Lipid Research 30, 1895-1906.

Association of Official Analytical Chemists (1990) Official Methods of Analysis, 15th ed. Arlington, VA: AOAC.

Balmir F, Staack R, Jeffrey E, Berber-Jeimenez MD, Wang L \& Potter SM (1996) An extract of soy flour influences serum cholesterol and thyroid hormones in rats and hamsters. Journal of Nutrition 126, 3046-3053.

Carr TP, Gallaher DD, Yang C \& Hassel CA (1996) Increased intestinal content viscosity reduces cholesterol absorption efficiency in hamsters fed hydroxypropyl methylcellulose. Journal of Nutrition 126, 1463-1469

Carroll KK (1991) Vegetable protein potential lipid-lowering effects. Medicine North America 4th Series 17, 2279-2282.

Folch J, Lees M \& Sloane-Stanley GH (1957) A simple method for the isolation and purification of total lipides from animal tissues. Journal of Biological Chemistry 226, 497-509.

Forsythe WA III (1995) Soy protein, thyroid regulation and cholesterol metabolism. Journal of Nutrition 125, 619S-623S.

Fumagalli R, Soleri L, Farina R, Musanti R, Mantero O, Noseda G, Gatti E \& Sirtori CR (1982) Faecal excretion studies in type II hypercholesterolemic patients treated with the soybean protein diet. Atherosclerosis 43, 341-353.

Grundy SM, Ahrens EH \& Miettinen TA (1965) Quantitative isolation and gas liquid chromatography analysis of total faecal bile acids. Journal of Lipid Research 6, 397-410.

Horton JD, Cuthbert JA \& Spady DK (1995) Regulation of hepatic $7 \alpha$-hydroxylase expression and response to dietary cholesterol in the rat and hamster. Journal of Biological Chemistry 270, 5381-5387.

Huff MW \& Carroll KK (1980) Effects of dietary protein on turnover, oxidation, and absorption of cholesterol, and on steroid excretion in rabbits. Journal of Lipid Research 21, 546558.

Huff MW, Hamilton RMG \& Carroll KK (1977) Plasma cholesterol levels in rabbits fed low fat, cholesterol free, semipurified diets: effects of dietary proteins, protein hydrolysates and amino acid mixtures. Atherosclerosis 28, 187-195.
Ishikawa F, Mizobuchi T, Aiyama R \& Yokokura T (1997) Gann Yobo shokuhin (Foods for cancer prevention) (patent). Japan Kokai Tokkyo Koho 08-051646.

Ishimoto K (1986) Quantitative analysis of bile acids in human feces by high performance liquid chromatography. Journal of the Wakayama Medical Society 37, 195-202.

Jackson EM, Lewis DS, McMahan CA \& Mott GE (1993) Preweaning diet affects bile lipid composition and bile acid kinetics in infant baboons. Journal of Nutrition 123, 14711479.

Jariwalla RJ, Sabin R, Lawson S \& Herman ZS (1990) Lowering of serum cholesterol and triglycerides and modulation of divalent cations by dietary phytate. Journal of Applied Nutrition 42, 18-28.

Jaskiewicz K, Weight MJ, Christopher KJ, Benade AJS \& Kritchevsky D (1987) A comparison of the effects of soyabean protein and casein on bile composition, cholelithiasis and serum lipoprotein lipids in the vervet monkey (Cercopithecus aetiops). British Journal of Nutrition 58, 257-263.

Kikuchi H \& Yajima T (1992) Correlation between water-holding capacity of different types of cellulose in vitro and gastrointestinal retention time in vivo of rats. Journal of the Science of Food and Agriculture 60, 139-146.

King RA, Broadbent JL \& Head RJ (1996) Absorption and excretion of the soy isoflavone genistein in rats. Journal of Nutrition 126, 176-182.

Knuiman JT, Beynen AC \& Katan MB (1989) Lecithin intake and serum cholesterol. American Journal of Clinical Nutrition 49, 266-268.

Martin PM, Horwits KB, Ryan DS \& McGuire WL (1978) Phytoestrogen interaction with estrogen receptors in human breast cancer cells. Endocrinology 103, 1860-1867.

Mathieson RA \& Kitts WD (1980) Binding of phytoestrogen and the hypothalamus of the ewe. Journal of Endocrinology 85, 317-323.

Meyer JH, Gu Y, Elashoff J, Reedy T, Dressmam J \& Amidon G (1986) Effects of viscosity and fluid outflow on postcibal gastric emptying of solids. American Journal of Physiology 250, G161-G164.

Nagata Y, Ishiwaki N \& Sugano M (1982) Studies on the mechanism of the antihypercholesterolemic action of soy protein and soy protein type amino acid mixtures in relation to their casein counterparts in rats. Journal of Nutrition 112 , 1614-1625.

Pandak WM, Doerner M, Heuman DM, Hylemon PB, Chiang JYL \& Vlahcevic ZR (1995) Expression of cholesterol $7 \alpha$ hydroxylase in response to cholesterol and bile acid feeding in the hamster and rat. Gastroenterology 108, A1141.

Potter, SM (1995) Overview of proposed mechanisms for the hypocholesterolemic effect of soy. Journal of Nutrition 125 , 606S-611S.

Potter SM, Jimenez-Flores R, Pollack J, Lone TA \& BerberJimenez MD (1993) Protein-saponin interaction and its influence on blood lipids. Journal of Agricultural and Food Chemistry 41, 1287-1291.

Potter SM, Pertile J \& Berber-Jimenez MD (1996) Soy protein concentrate and isolated soy protein similarly lower blood serum cholesterol but differently affect thyroid hormones in hamsters. Journal of Nutrition 126, 2007-2011.

Russell DW \& Setchell KDR (1992) Bile acid biosynthesis. Biochemistry 31, 4738-4749.

Sacks FM \& Walsh BW (1990) The effects of reproductive hormones on serum lipoproteins: unresolved issues in biology and clinical practice. Annals of the New York Academy of Sciences 592, 272-285.

Sanchez A \& Hubbard RW (1991) Plasma amino acids and the insulin/glucagon ratio as an explanation for the dietary protein 
modulation of arteriosclerosis. Medical Hypotheses 35, 324 329.

Schaefer EJ, Foster DM, Zech LA, Rindgren FT, Brewer HB Jr \& Levy RI (1983) The effect of estrogen administration on plasma lipoprotein metabolism in premenopausal females. Journal of Clinical Endocrinology and Metabolism 57, 262-267.

Schwarz M, Lund EG, Setchell KDR, Kayden HJ, Zerwekh JE, Bjorkhem I, Herz J \& Russell DW (1996) Disruption of cholesterol $7 \alpha$-hydroxylase gene in mice. Journal of Biological Chemistry 271, 18024-18031.

Sharma RD (1978) Isoflavones and hypercholesterolemia in rats. Lipids 14, 535-540.

Stampfer MJ, Colditz GA, Willett WC, Manson JE, Rosner B, Speizer FE \& Hennekens CH (1991) Postmenopausal estrogen therapy and cardiovascular disease: ten-year follow-up from the Nurses' Health Study. New England Journal of Medicine 325, $756-762$.

Sugano M \& Koba K (1993) Dietary protein and lipid metabolism: a multifunctional effect. Annals of the New York Academy of Sciences 676, 215-222.

Sugano M, Goto S, Yamada Y, Yoshida K, Hashumoto Y, Matsui T \& Kimoto M (1990) Cholesterol-lowering activity of various undigested fractions of soybean protein in rats. Journal of Nutrition 120, 977-985.

Terpstra AHM, Holmes JC \& Nicolosi RJ (1991) The hypocholesterolemic effect of dietary soybean protein vs. casein in hamsters fed cholesterol-free or cholesterol-enriched semipurified diets. Journal of Nutrition, 121, 944-947.

Uchida K (1992) Bile acid metabolism and intestinal flora. Bifidus $5,157-172$.

Uchida K, Makino S \& Akiyoshi T (1985) Altered bile acid metabolism in non obese, spontaneously diabetic (NOD) mice. Diabetes 24, 79-83.

Uchida K, Nomura Y, Kadowaki M, Yakase H, Takano K \& Takeuchi N (1978) Age-related changes in cholesterol and bile acid metabolism in rats. Joumal of Lipid Research 19, 544 552.

Uchida K, Nomura Y \& Takeuchi N (1980) Effect of cholic acid, chenodeoxycholic acid, and their related bile acids on cholesterol, phospholipid, and bile acids levels in serum, liver, bile, and faeces of rats. Journal of Biochemistry 87, 187-194.

Vahouny GV, Connor WE, Subramaniam S, Lin DS \& Gollo LL (1983) Comparative lymphatic absorption of sitosterol, stigmasterol, and fucosterol and differential inhibition of cholesterol. American Journal of Clinical Nutrition 37 , 805-809.

Van Erpecum KJ, Van Berge Henegouwen GP, Verschoor L, Stoelwinder B \& Willekens FLH (1991) Different hepatobiliary effects of oral and transdermal estradiol in postmenopausal women. Gastroenterology 100, 482-488.

Zar JH (1984) Biostatistical Analysis, 2nd ed. Englewood Cliffs, NJ: Prentice Hall. 